Пудичева Г. О., докторант

Одеський національний економічний університет

м. Одеса, Украӥна

DOI: https://doi.org/10.30525/978-9934-26-028-5-54

\title{
ПЕРЕВАГИ ТА НЕДОЛІКИ \\ ЕКОНОМЕТРИЧНИХ МЕТОДІВ ОЦІНКИ ЕФЕКТИВНОСТІ В ЕНЕРГЕТИЧНІЙ СФЕРІ
}

Мета енергетичного ланцюга постачань - створити енергетичні послуги (електричну та/або теплову енергію) з енергетичних ресурсів та найбільш ефективним чином забезпечити ними кінцевого споживача. Історично така ефективність зводилась до зниження витрат та зростання прибутку.

Під ефективністю варто розуміти ступінь відповідності певних ефектів величинам, що характеризують обсяги ресурсів, витрат, доходів тощо. Тобто, у термінології процесного підходу ефективність являє собою співвідношення між «виходами» та «входами».

Бажаним «виходом» виробничої системи є енергія певного виду. Однак виробництво енергії з традиційних джерел супроводжується такими небажаними виходами, як діоксид вуглецю, діоксид сірки, оксиди азоту та ін. Безумовно, вони повинні бути враховані при розрахунку ефективності виробників енергії в ланцюгах постачань, оскільки екологічна ефективність є передумовою спрямованості на шлях сталого розвитку.

Для того, щоб оцінити ефективність виробників енергії в існуючих ланцюгах постачання, враховуючи всі аспекти сталого розвитку, необхідно застосувати кількісні економетричні методи аналізу.

Як вказує В.В. Вітвіцький, ефективність підприємства за використання економетричного підходу розраховується на основі близькості значень показників окремого підприємства до потенційної або фактичної межі ефективності. Межа ж ефективності розраховується за виробничою функцією [1, с. 70]. 
Загальноприйняті методи таких досліджень поділяються на дві групи: параметричні та непараметричні. Параметричні методи засновані на економічній оцінці точної функціональної форми виробничої функції. Непараметричні методи використовують методи лінійного програмування. До параметричних методів належать: метод стохастичної межі (Stochastic Frontier Approach (SFA), метод стохастичного граничного аналізу), метод без специфікації розподілення (Distribution Free Approach (DFA)) та метод широкої межі (Thick Frontier Approach (TFA), метод щільної межі). До непараметричних відносять метод оболонкового аналізу (Data Envelopment Analysis (DEA), аналіз згортання даних, аналіз середовища функціонування) та метод вільної оболонки (Free Disposal Hull (FDH), метод вільного розташування оболонки, метод вільного розміщення оболонки). Усі ці методи засновані на побудові та званої «межі ефективності» («границі ефективності»). Дослідники пов’язують дане поняття 3 межею виробничих можливостей та виробничою функцією. Кожен з наведених методологічних підходів має свої особливості застосування та може бути використаний для оцінки ефективності роботи підприємств в енергетичній галузі.

У таблиці 1 представлено переваги та недоліки цих методів.

В залежності від цілей дослідження, об'єктів аналізу та переліку факторів, які, на думку дослідника, чинять вплив на ефективність роботи підприємств, можна обрати той чи інший метод, який дозволить отримати результати, що можуть бути використані для подальшої розробки енергетичної політики.

Починаючи зі світової нафтової кризи 1973-1974 pp. різноманітні методи економіко-математичного моделювання набули поширення при аналізі енергетичної галузі в усьому світі. Екологічні проблеми, що набули розголосу у суспільстві в 1980-х pр., викликали хвилю інтересу серед дослідників до вирішення комплексних проблем, пов'язаних одночасно 3 існуючими викликами в енергетиці та екології. 
Переваги та недоліки економетричних методів для оцінки ефективності економічних об'сктів

\begin{tabular}{|c|c|c|c|}
\hline $\begin{array}{c}\text { Група } \\
\text { методів }\end{array}$ & Метод & Переваги & Недоліки \\
\hline \multirow{3}{*}{$\begin{array}{c}\text { Пара- } \\
\text { метричні }\end{array}$} & SFA & $\begin{array}{c}\text { - Припускає існування } \\
\text { функціонального зв’язку між } \\
\text { входом та виходом; } \\
\text { - Можливо відділити } \\
\text { похибки та статистичний } \\
\text { шум від неефективності }\end{array}$ & $\begin{array}{c}\text { - Необхідно точно } \\
\text { визначати } \\
\text { функціональну форму } \\
\text { зв’язку; } \\
\text { - Дозволяють оцінити } \\
\text { об'єкт лише з одним } \\
\text { «виходом» }\end{array}$ \\
\hline & DFA & $\begin{array}{c}\text { - Відсутня необхідність } \\
\text { визначати характер } \\
\text { розподілу; } \\
\text { - Висока надійність } \\
\text { результатів методу; } \\
\text { - Усереднення похибок в } \\
\text { даних до нуля } \\
\end{array}$ & $\begin{array}{c}\text { - Зміна ефективності } \\
\text { описується як середнє } \\
\text { відхилення від кращого } \\
\text { об'єкта; } \\
\text { - Ефективність } \\
\text { оцінюється на основі } \\
\text { рангів }\end{array}$ \\
\hline & TFA & $\begin{array}{c}\text { - Оцінка проводиться лише } \\
\text { для груп ефективних } \\
\text { об'єктів }\end{array}$ & $\begin{array}{c}\text { - Необгрунтованість } \\
\text { процентиля груп у } \\
\text { розрахунках; } \\
\text { - Оцінюється не } \\
\text { ефективність кожного } \\
\text { об’єкта, а загальна } \\
\text { ефективність }\end{array}$ \\
\hline \multirow[t]{2}{*}{$\begin{array}{l}\text { Непара- } \\
\text { метричні }\end{array}$} & DEA & $\begin{array}{c}\text { - Існують варіанти моделей } \\
\text { з багатьма входами та } \\
\text { виходами; } \\
\text { - Немає необхідності у } \\
\text { встановленні форми зв’язку } \\
\text { між входами та виходами; } \\
\text { - Знижується } \\
\text { суб'єктивність оцінки, } \\
\text { оскільки використовуються } \\
\text { середньозважені ваги } \\
\end{array}$ & $\begin{array}{c}\text { - Результати } \\
\text { оцінювання не містять } \\
\text { вектору помилок; } \\
\text { - Результати } \\
\text { змінюються в залежності } \\
\text { від кількості факторів у } \\
\text { моделі }\end{array}$ \\
\hline & $\mathrm{FDH}$ & $\begin{array}{c}\text { - } \text { Дозволяє більш точно } \\
\text { оцінити ефект масштабу; } \\
\text { - } \text { Не містить обмежень, } \\
\text { пов’язаних з технологією } \\
\text { виробництва; } \\
\text { - Менше завищує технічну } \\
\text { ефективність }\end{array}$ & $\begin{array}{c}\text { - Результати } \\
\text { оцінювання не містять } \\
\text { вектору помилок; } \\
\text { - Результати } \\
\text { змінюються в залежності } \\
\text { від кількості факторів у } \\
\text { моделі }\end{array}$ \\
\hline
\end{tabular}

Джерело: узагальнено автором на основі [2-8] 
Саме тому в дослідженні ефективності використання енергії на рівні підприємств різних галузей, а також на регіональному та національному розглянуті підходи також знайшли своє застосування.

Хоча на оцінці енергетичної та екологічної ефективності різноманітних галузей зосереджена численна кількість наукових публікацій, все ж питання оцінки ефективності енергетичних ланцюгів постачань залишаються недостатньо висвітленими, зокрема, недостатньо уваги приділено врахуванню екологічних показників.

На наш погляд, оцінювання ефективності діяльності підприємств в енергетичному секторі $\epsilon$ однією 3 найбільш складних задач в управлінні. Це пов'язано з тим, що доволі важко визначити, яким чином процеси, які відбуваються в енергетичному господарстві, беручи до уваги їх екологічні наслідки, впливають на ефективність роботи підприємств енергетичної галузі в цілому. Саме застосування економетричних методів дозволить провести такий аналіз, результати якого можуть вплинути на формування енергетичних ланцюгів постачання.

\section{Література:}

1. Вітвіцький В.В. Формування i класифікація системи показників продуктивності в аграрних підприємствах. Вісник аграрної науки. 2016. № 9. C. 67-71.

2. Meeusen W., Den Broeck J. Efficiency Estimation from Cobb-Douglas Production Function with Composed Error. International Economic Review. 1977. Vol. 18. No. 2. Pp. 435-444.

3. Ding Y., Liu X. A comparative analysis of data-drive methods in building energy benchmarking. Energy \& Buildings. 2020. Vol. 209. 109711. DOI: https://doi.org/10.1016/j.enbuild.2019.109711.

4. Савельева Н.К. Сравнительная характеристика количественных методов оценки эффективности деятельности банка. Международный бухгалтерский yчет. № 4. 2016. C. 18-34.

5. Potvin C., Roff D.A. Distribution_Free and Robust Statistical Methods: Viable Alternatives to Parametric Statistics. Ecology. 1993/ Vol. 74. No. 6. Pp.1617-1628. 
6. Горобець Т.А., Гончарук А.Г. Методичний підхід до оцінки ефективності діяльності підприємств малого та середнього бізнесу. Проблеми системного підходу в економіці. 2019. № 5(73). С. 77-86.

7. Lovell C.A.K., Eeckaut P.V. Frontier Tales: Dea and FDH. Mathematical Modelling in Economics. 1993. pp. 446-457. DOI: https://doi.org/10.1007/978-3-64278508-5_43

8. Вітвіцький В.В. Методичні підходи до оцінки конкурентоспроможності аграрних підприємств. Вісник ЖНАЕУ. 2015. № 2 (51), т. 2. С. 207-213. 